\title{
INFLUENCE OF INTRINSIC AND EXTRINSIC FOOD ATTRIBUTES ON CONSUMERS' ACCEPTANCE OF REFORMULATED FOOD PRODUCTS: A SYSTEMATIC REVIEW
}

\section{VPLIV NOTRANJIH IN ZUNANJIH LASTNOSTI PREOBLIKOVANIH ŽIVIL NA SPREJEMLJIVOST MED POTROŠNIKI: SISTEMATIČNI PREGLED LITERATURE}

\author{
Anja BOLHA ${ }^{*}$, Urška BLAZNIK², Mojca KOROŠEC1
}

\author{
${ }^{1}$ University of Ljubljana, Biotechnical Faculty, Jamnikarjeva 101, 1000 Ljubljana, Slovenia
}

${ }^{2}$ National Institute of Public Health, Trubarjeva 2, 1000 Ljubljana, Slovenia

Received: Jul 3, 2020

Review article

Accepted: Nov 23, 2020

ABSTRACT

\section{Keywords:}

reformulation intrinsic attributes, extrinsic attributes, informed conditions, blind conditions, expected conditions

\section{IZVLEČEK}

Ključne besede: preoblikovanje živil, notranje lastnosti, zunanje lastnosti, informiran pogoji, slepi pogoji, pričakovani pogoji
Introduction: Reducing the salt, sugar and fat content of food is recognised worldwide as one of the strategies available for reducing the incidence of obesity and non-communicable diseases. The food industry has a major influence on achieving these goals by preserving intrinsic (chemical and sensory properties) and modifying extrinsic (food packaging and other external information) food attributes that can influence purchasing decisions. This article is a literature review of studies that analyse the influence of intrinsic and/or extrinsic attributes on consumer product preference and purchasing decisions.

Methods: A keyword search for relevant studies was conducted using Web of Science, an interdisciplinary electronic resource. Articles from other sources were also included and systematically reviewed.

Results: The search string identified 266 results. Thirty-eight articles were included in the final analysis and coded according to intrinsic and extrinsic food attributes, reformulated nutrient, food category, condition, research methods, consumer response, study location and sample size. There are several authors investigating the effect of intrinsic rather than extrinsic product attributes. Most research deals with processed foods in the category of milk and dairy products, followed by sweetened fruit juices, meat products, sweets and bread. Salt content is the attribute most often reduced, followed by sugar and fat.

Conclusions: Consumers find it hard to swap potential health benefits for hedonic attributes. When evaluating products in expected conditions, they usually rate the reformulated product more highly than the conventional one, while in informed conditions they usually choose the regular product. When products are labelled with a traffic light or nutritional warnings, consumers opt for a reformulated product, even in informed conditions. This review highlights the heterogeneity between food groups, and the fact that many factors influence consumers' product preferences and purchasing decisions. The product should be analysed as a whole and tested in blind, expected and informed conditions, as each individual factor represents a phase of the consumer purchasing decision. The extent of nutrient reduction should be determined by calculating the difference threshold, and the industry should reformulate products gradually based on how consumers detect the reduction.

Uvod: Zmanjševanje vsebnosti soli, sladkorja in maščob $v$ živilih je prepoznano kot ena izmed strategij za zmanjševanje pojava debelosti in kroničnih nenalezljivih bolezni. Velik pomen pri doseganju ciljev imajo proizvajalci živil, ki lahko z ohranjanjem notranjih (kemijske in senzorične lastnosti) in oblikovanjem zunanjih lastnosti živil (podatki na embalaži in druge informacije) vplivajo na potrošnikovo odločitev za nakup. Ta članek predstavlja pregled literature s področja vpliva notranjih in zunanjih lastnosti preoblikovanih živil na priljubljenost in odločitev potrošnikov za nakup.

Metode: Z uporabo ključnih besed smo v bibliotekarski bazi Web of Science poiskali vse relevantne študije. Vključili smo tudi članke iz drugih virov in jih sistematično pregledali.

Rezultati: Iskalni niz je pokazal 266 zadetkov. V končno analizo se je uvrstilo 38 člankov, ki smo jih kodirali glede na notranje in zunanje lastnosti izdelka, preoblikovano hranilo, kategorijo živila, pogoj izvedbe študije, raziskovalne metode, odziv potrošnikov, lokacijo študije in velikost vzorca. Več avtorjev preučuje notranje lastnosti preoblikovanih izdelkov. Največ raziskav obravnava preoblikovana živila v kategoriji mleka in mlečnih izdelkov, sledijo nektarji in mesni izdelki ter sladkarije in kruh. Največkrat znižujejo vsebnost soli, sledita sladkor in maščoba.

Zaključki: Potrošniki zelo težko sprejmejo kompromis med senzoričnimi zaznavami in potencialnimi koristmi za zdravje. Kadar izdelke ocenjujejo $v$ pričakovanem pogoju, se večinoma odločijo za preoblikovani izdelek, $v$ informiranem pogoju pa večkrat izberejo običajnega. Kadar so izdelki označeni s prehranskim semaforjem ali poudarjenimi opozorili, potrošnike to odvrne od nepreoblikovanih živil in lažje se odločijo za preoblikovano živilo tudi $v$ informiranem pogoju. Pregledni članek izpostavlja heterogenost med skupinami živil in vpliv mnogih dejavnikov na všečnost in nakupno odločitev potrošnikov. Izdelek je treba obravnavati kot celoto in ga testirati tako pod slepim, pričakovanim in informiranim pogojem, saj vsak predstavlja fazo v odločitvi potrošnika za prvi oziroma ponovni nakup. Delež znižanja je dobro določiti s testiranjem praga razlikovanja in izdelke preoblikovati postopoma. 


\section{INTRODUCTION}

There is increasing prevalence of obesity, type- 2 diabetes, coronary heart disease and other non-communicable diseases related to over-consumption of energy-dense foods high in fat, sugar and salt (1). As a preventive measure, the World Health Organization (WHO) strategy addresses the problem through the reformulation of food products, thereby creating an environment that encourages healthier consumer choices (2).

The reformulation of food by means of healthier alternatives has the potential to improve diet and health, with the strongest evidence currently available for salt reduction (3). The best food reformulation initiatives have shown that the goals can be achieved through agreement and cooperation between different stakeholders, the use of symbols and labels, public awareness-raising and education (4).

Increasing attention has been given to interventions that directly or indirectly appeal to the food industry to change the composition of their food products. However, food manufacturers are faced with the challenge of how to maintain the basic characteristics that drive consumers when purchasing the product, such as taste, texture and shelf life (5). Consumer opinion is formed on the basis of the intrinsic and extrinsic attributes of products. Intrinsic attributes are part of a product (taste, smell, texture and appearance), as well as its chemical and physical composition (6). By contrast, extrinsic attributes belong to (but are not part of) the food. Such attributes include labelling, packaging, nutritional claims, price, and any other source of information about the product. Previous studies on the attributes of food products have shown that, for consumers, both types of attribute are important when selecting foods, particularly taste, labelling and price (7).

Reformulated food products should be healthy, but still taste good. Consumer acceptance is therefore tested in different conditions to determine the significance of individual characteristics. The product can be tested in blind, informed or expected conditions. In blind conditions, the consumer evaluates the intrinsic attributes (8-13); in informed conditions, external information (nutritional information, packaging, health claims, etc.) is provided by means of sensory evaluation (14-18); and in expected conditions, a product is evaluated only on the basis of external information (19-22).

The liking of a product and its acceptability are measured by various scales, the most common being the 9-point hedonic scale $(10,12,23,24)$. To determine the intensity of a particular trait, the JAR (Just About Right) scale is the most appropriate $(9,12,23,25)$. The CATA (Check All That Apply) method is most often used in consumer studies to profile product characteristics. It consists of a list of words, with the consumer asked to select those appropriate to describe the product (26). RATA or (Rate All That Apply) is a version of CATA questions, with the added intensity rating of selected descriptors $(23,26)$.

The aim of our review is to determine how intrinsic and extrinsic food attributes influence a consumer's decision to choose reformulated foods, and which attributes researchers place greater emphasis on.

\section{METHODS}

The study design followed the PRISMA protocol (27) and is presented in Figure 1. A keyword search of the Web of Science (www.webofknowledge.com) interdisciplinary electronic resource was conducted as follows: TOPIC: (food and (sensory or consumer)) AND TITLE: (fat* or sugar* or salt* or sodium* or fiber* or calorie* or product*) AND TITLE: (enrich* or reduc* or limit* or reform* or low) AND TOPIC: (choice or preference or accept*) AND TOPIC: (extrinsic or label* or claim* or price or brand or packag* or intrinsic or taste or smell or flavor or flavour or appearance) NOT TOPIC: (animal or mice or rat). As at August 2019, the search engine displayed 231 relevant articles. Thirty-five relevant articles were identified from other sources, giving a total of 266 articles included in the screening. After removing the duplicates, studies that empirically investigated the intrinsic and/or extrinsic attributes of reformulated food products were selected. By reviewing the titles and abstracts, articles that were not fully accessible in English were excluded. A total of 67 articles were relevant for the purposed of content analysis.

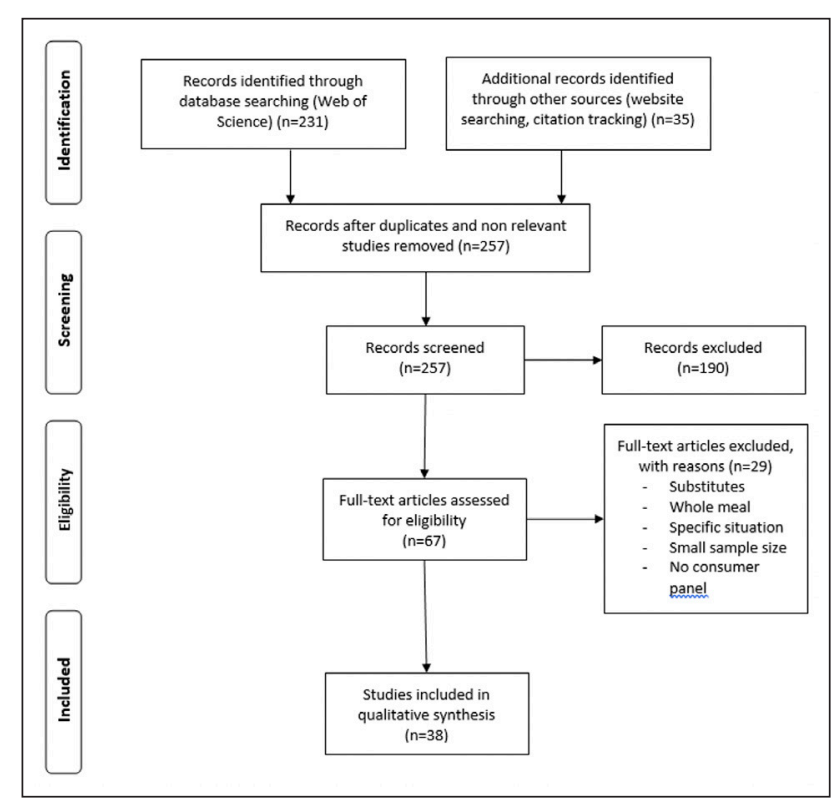

Figure 1. Article selection protocol for literature review. 
Based on content, the following were excluded: (a) studies $(\mathrm{n}=29)$ that dealt with flavour substitutes (e.g. spices, $\mathrm{KCl}$, sweeteners), functional ingredients, and whole meals instead of individual products; (b) studies that referred to groups of people with specific needs (only young men, patients, children, soldiers, etc.); and (c) studies that involved only professional sensory panels. Thirtyeight relevant articles were included for the purposes of qualitative synthesis. A review was conducted of information on reformulated nutrients, the food product category, the condition of the study (blind, informed, expected), product attributes (intrinsic, extrinsic), research methods, consumer response, study location and sample size. The descriptive properties of the studies included have been summarised in Zotero (28) and Excel (29).

\section{RESULTS}

\subsection{Basic information}

Of the 38 relevant studies on intrinsic and/or extrinsic food product attributes affecting consumer acceptance of reformulated food products, 20 dealt with salt, 16 with sugar and 16 with fats. Two studies focused on all three nutrients in different food categories $(22,30)$, while ten studies focused on two different nutrients. Eight studies examined changes in more than one food category at a time. Most research on this topic $(n=15)$ focused on the reformulation of dairy products, followed by soft drinks, sweets and meat products. The majority of the sensory studies $(n=26)$ included products developed by the researchers themselves, while seven used commercially available products.

The consumer panels in the studies reviewed consisted of between 50 (31) and 800 (16) participants, with a median of 127. Online research that collected data on external product attributes had, on average, more participants than laboratory-, home- or field-based sensory analysis. Research involved consumers who, at least occasionally, consumed the tested product, were free of dietary allergies and intolerances, and were generally healthy. Most authors cited compliance with ethical standards.

\subsection{Research conditions}

Most studies $(n=27)$ were conducted in controlled conditions, i.e. in laboratory settings. In three studies (9, 30, 32), consumers had the product available for consumption at home, in addition to weekly sensory analysis in the lab. Home-testing studies lasted between one (31) and 12 weeks (32). In six studies (19, 22, 25, 33$35)$, the analyses were carried out in the field, mostly in canteens or supermarkets. Three studies were conducted via an online questionnaire $(20,36,37)$, where only extrinsic product attributes were evaluated (the impact of the brand, nutritional and health claims, information on the packaging, and price).

Only two of the articles reviewed involved an evaluation of product attributes in blind, expected and informed conditions $(16,18)$. Eighteen studies tested only in blind conditions, which meant that only the intrinsic attributes of the product were evaluated. Studies that examined expected conditions alone $(n=6)$ were conducted online $(20,36,37)$, in the field $(22)$ or in a laboratory $(21,38)$. Only in one of the studies were product attributes evaluated in informed conditions alone (17). In general, the majority of researchers evaluated products in blind conditions, with 12 studies combining this with informed conditions.

\subsection{Measuring consumer response}

Product acceptability was measured most often $(n=26)$ using different response scales (9-point hedonic scale, 100 $\mathrm{mm}$ scale, JAR). Researchers were also interested in the perception of healthiness during product tasting $(15,17$, $31,36-38)$ or only while observing the extrinsic attributes $(20,37)$. Descriptive product properties were evaluated in seven studies $(8,15,19,39-42)$ using CATA or $(n=1)(23)$

Table 1. Overview of studies by food category and nutrient reduction.

\begin{tabular}{llll}
\hline Food category & Reduced nutrient & Food product & No of studies \\
\hline Dairy products & salt, fat & cheese, dairy drink, yoghurt, quark, butter & 15 \\
Soft drinks & sugar & cola, sweetened fruit juices, tomato juice & 7 \\
Sweet snacks & sugar, salt, fat & biscuits, chocolate, bars, muffins, MeM sweets & 7 \\
Meat products & salt, fat & sausages, frankfurters, ham, burgers & 7 \\
Bread & salt & bread & instant/dehydrated chicken soup, tomato soup, vegetable soup \\
Soups & salt & chips & 3 \\
Salty snacks & salt & jam, canned beans, pickles & 2 \\
Fruits and vegetables & salt, sugar & fat spread & 2 \\
Other & fat & & 1 \\
\hline
\end{tabular}


RATA methods. Twelve studies studied willingness to buy, and three evaluated willingness to purchase $(21,36,43)$ through qualitative research.

Among the 38 studies included, 33 focused on intrinsic attributes, more precisely hedonic acceptability and sensory properties, with taste being the most important $(n=22)$. Since the term "flavour" refers to a combination of olfactory and gustatory sensations (44), studies that ranked "flavour/flavor" were counted under both the "taste" and "odour" categories. Texture was evaluated in 16 studies and appearance in nine studies. In addition to assessing the liking of individual sensory traits with different hedonic scales, consumers also evaluated the intensity of a stimulus $(n=12)$ on the JAR scale.

The impact of extrinsic attributes was observed in 20 of the 38 studies included, with 15 considering the influence of both intrinsic and extrinsic attributes, and five considering extrinsic attributes alone. The impact of nutritional/health information was most often identified in relation to nutritional and health claims, the nutritional table, front-of-pack labelling $(15,16,19,22)$, the highlighting of food properties (e.g. sensory properties, nutritional composition, "light product"), and information on nutrients content and their effects provided orally. In addition to nutritional information, the impact of branding was examined in two studies $(20,36)$, the impact of price in three studies $(10,21,37)$ and the impact of packaging in one study (38).

\section{DISCUSSION}

Our review showed that studies mostly addressed the sensory perception of intrinsic attributes, which was most likely related to doubt as to whether consumers would like the modified products and re-purchase them.

The decision to purchase a reformulated product is affected by the size, shape and colour of the packaging (38). Most low-fat and/or low-sugar products are currently being presented in lighter-coloured packaging, suggesting that this is a "light" product. However, Tijssen et al. (38) have shown that packaging products in warmer, saturated and less bright colours increases the sensory perception and affinity with the product, which means that the existing light-coloured packaging discourages consumers from buying a reformulated product.

Studies that considered extrinsic attributes alone found a positive correlation between various types of front-ofpack information and product purchase. Ares et al. (22) investigated the impact of nutritional warnings and found that a negative mark on the front of a regular product encouraged the purchase of a reformulated product with better nutritional composition. Schnettler et al. (20), who studied the impact of nutritional and health claims on meat products (hot dogs), came to similar conclusions. Their study found that front-of-pack nutritional information influenced a consumer's willingness to buy a reformulated product. It is also important that consumers understand the nutritional information on the package correctly. Franco-Arellano et al. (45) reported that, overall, front-ofpack nutritional labelling might exert a stronger influence on consumer perception than nutritional claims, since it was likely helpful for consumers with different levels of health literacy.

When consumers taste the product in addition to seeing it or receiving product information, their ratings might change (16). Indeed, it is very difficult for consumers to accept the compromise between sensory properties and potential health benefits. In expected conditions, consumers preferred products with positive front-ofpack nutritional information. However, after tasting their ratings changed. Studies show that in informed conditions, sensory perceptions outweigh positive nutritional information $(16,18,32,43)$. Only in some cases $(15,22)$ did nutritional information in the form of a coloured traffic light direct consumers to choose a reformulated food product, even in informed conditions. However, positive nutritional information can still have a negative effect on sensory perception. Consumers may relate the fact that the product is sugar-free with diabetic products, and therefore with negative emotions (18).

In the past, the causes of obesity were sought primarily in excessive fat intake; the first studies on reformulated food products therefore attempted to determine the acceptability of low-fat foods $(31,32)$. The favourable extent of fat reduction depends on the type of product being reformulated. Sweets, dairy and meat products were most often examined. In biscuits, fat content should be easier to reduce than sugar content (9), while front-ofpack information on fat reduction had a negative effect on sensory perception (18). It may therefore be reasonable to carry out such reductions without specifically informing consumers. The promotion of good taste and pleasure may be more effective for consumers than health promotion (46). However, hedonic claims must be taken with care, as they may adversely affect the liking of a product if it does not meet the expectations (19).

In informed conditions, consumers give a lower hedonic score when information on sugar reduction is provided, while salt reduction affects the hedonic score to a lesser extent. WHO indicated that salt reduction is recognised as the best food reformulation strategy for reducing the impact of unhealthy diets on the incidence of chronic noncommunicable diseases (47). Torrico et al. (14) reported that salt reduction information had a positive impact on the willingness to purchase potato chips, with same proving true for cheese (48) and fat spread (31). Information has also been shown to have a negative impact on willingness 
to purchase reduced-sugar yoghurt (43). Lima et al. (16) demonstrated, with reference to sweetened grape juice and chocolate milk, that sugar information convinces consumers to choose a less sweet product in expected conditions, but not in informed conditions.

Soft drinks have been identified as a major source of added sugar in the diet, and is one of the top priorities for reducing the burden of chronic non-communicable diseases worldwide (2). The replacement of sugary drinks with water or with beverages with reduced sugar content is recognised as one of the more effective interventions to reduce sugar consumption (49). However, consumers are accustomed to tasting sweet things and are not equally receptive to products with reduced sugar content (12). That said, a small reduction in sugar content from 10 to $8.5 \%$ did not reduce the acceptability of a soft drink, (39). Gradual reduction is therefore proposed as an effective strategy. Oliveira et al. (40) found similar effects in sweetened fruit juice when sugar content was reduced by $10-20 \%$.

The acceptance of low-sugar drinks has been one of the main subjects of sensory research on reformulated food products in recent years in South America (15, 16, 19, 39, 40), suggesting that the problem of obesity is currently being addressed through the reduction in dietary sugar as well. In Europe, sugar, salt and fat are approximately equally well-represented in studies. This may be linked to the results of the WHO report on the prevalence of chronic non-communicable diseases (47). Countries in South America are already making good progress in meeting their goals of reducing high blood pressure, even as the obesity trend is growing. In European countries, high blood pressure and cardiovascular disease remain the main reasons for premature death from chronic noncommunicable diseases. It is therefore advisable to reduce all "problematic" nutrients and pay particular attention to reducing salt intake.

According to a systematic review conducted in 2014 (50), over 59 programmes of food reformulation through salt reduction have been identified worldwide. Thirty-eight countries have set targets for salt content in products, and nine have already set legally defined salt limits in some food products. On the other hand, 17 countries have already reported reduced salt content in commercially available products, mostly bread. Four of the studies reviewed reduced the salt content of bread. A longitudinal home-based study (11) found that the salt content of bread can be reduced by a quarter without affecting whether a consumer liked it or not (although consumers did detect a significant difference in salinity). A similar phenomenon was reported by Kovač and Knific (51) in preschool children who accepted normal and less salty bread of different varieties equally. Moreover, they did not even associate those pieces of bread with the concept of "less salty". In other studies (33), consumers are not positive about changes in salt content, but positive information about added healthy ingredients partly convinces them to choose bread with less salt. When interpreting findings, it is necessary to pay attention to the amount of salt in the bread before and after the reduction, not just the percentage of reduction. Girgis et al. (11), for example, reduced salt content from $2 \%$ to $1.5 \%$ of flour weight, while Rodbotten et al. (33) reduced salt from $1.3 \%$ to $0.6 \%$ of flour weight. Antunez et al. (8) found that changing the salt content of bread significantly affected consumer preference, but that the change depended on the intervals and proportions of salt reduction. For example, reducing salt content from $2 / 1.8 \%$ to $1.38 / 1.25 \%$ of flour weight had a statistically significant effect on the consumer's hedonic score, while there was no significant difference in hedonic scores in samples with $1.61 \%$ of salt compared to samples with $1.8-2 \%$ salt or with $1.25 \%$ salt by weight of flour. Therefore, Antunez et al. (8) propose a reformulation with a gradual decline in salt levels, thereby accustoming consumers to a taste change within their difference threshold. The gradual reduction of these substances in bread, beverages and dairy products is suggested as an effective strategy by several other authors $(24,25,41)$.

\section{CONCLUSIONS}

Every reformulated food product should be considered as a whole. Consumer purchasing decisions are not only influenced by sensory perception, but can also be positively or negatively affected by all the information the consumer receives, whether it is extrinsic information on the product itself or information received from advertisements or merchants. Further research on consumer preference for reformulated food products should be conducted under blind, expected and informed conditions, as each reflects a different process in the consumer's decision to buy the product for the first time or their decision to re-purchase it. According to the suggestions made in the different studies included in this review, gradual nutrient reduction below the average differentiation threshold has the greatest potential for persuading consumers to accept a reformulated food product. When assessing consumer preferences, the researcher must take into account the consumer's different personal traits as well as their taste predispositions. Different strategies may be efficient for identified groups of consumers. Food product reformulation with a reduction in salt, sugar and fats has great potential for reducing diet-related non-communicable diseases, but actions need to be carefully communicated and contain no radical changes that could result in negative consumer response. 


\section{CONFLICT OF INTEREST}

The authors declare that no conflicts of interest exist.

\section{FUNDING}

This work was not funded.

\section{ETHICAL APPROVAL}

The method used in this systematic literature review involves no ethical issues. No ethical approval was therefore necessary.

\section{REFERENCES}

1. Ng M, Fleming T, Robinson M, Thomson B, Graetz N, Margono C, et al. Global, regional, and national prevalence of overweight and obesity in children and adults during 1980-2013: a systematic analysis for the Global Burden of Disease Study 2013. Lancet. 2014;384:766-81. doi: 10.1016/S0140-6736(14)60460-8.

2. WHO. Global action plan for the prevention and control of noncommunicable diseases 2013-2020. World Health Organisation, Geneva, 2013.

3. Federici C, Detzel P, Petracca F, Dainelli L, Fattore G. The impact of food reformulation on nutrient intakes and health: a systematic review of modelling studies. BMC Nutr. 2019;5:2. doi: 10.1186/s40795-0180263-6.

4. Truskova I. Best practices of member states in food reformulation: survey on member states "trio questionnaire 2016", 2016.

5. van Raaij J, Hendriksen M, Verhagen H. Potential for improvement of population diet through reformulation of commonly eaten foods. Public Health Nutr. 2009;12:325-30. doi: 10.1017/S1368980008003376.

6. Piqueras-Fiszman B, Spence $C$. Sensory expectations based on productextrinsic food cues: an interdisciplinary review of the empirical evidence and theoretical accounts. Food Qual Prefer. 2015;40:165-79. doi: 10.1016/j.foodqual.2014.09.013.

7. Symmank C. Extrinsic and intrinsic food product attributes in consumer and sensory research: literature review and quantification of the findings. Manag Rev Q. 2019;69:39-74. doi: 10.1007/s11301-018-0146-6.

8. Antunez L, Gimenez A, Ares G. A consumer-based approach to salt reduction: case study with bread. Food Res Int. 2016;90:66-72. doi: 10.1016/j.foodres.2016.10.015.

9. Biguzzi $C$, Schlich $P$, Lange $C$. The impact of sugar and fat reduction on perception and liking of biscuits. Food Qual Prefer. 2014;35:41-7. doi: 10.1016/j.foodqual.2014.02.001.

10. Childs JL, Drake M. Consumer perception of fat reduction in Cheese. J Sens Stud. 2009;24:902-21. doi: 10.1111/j.1745-459X.2009.00243.

11. Girgis S, Neal B, Prescott J, Prendergast J, Dumbrell S, Turner C, et al. A one-quarter reduction in the salt content of bread can be made without detection. Eur J Clin Nutr. 2003;57:616-20. doi: 10.1038/ sj.ejcn.1601583.

12. Markey O, Lovegrove JA, Methven L. Sensory profiles and consumer acceptability of a range of sugar-reduced products on the UK market. Food Res Int. 2015;72:133-9. doi: 10.1016/j.foodres.2015.03.012.

13. Mitchell M, Brunton NP, Wilkinson MG. The influence of salt taste threshold on acceptability and purchase intent of reformulated reduced sodium vegetable soups. Food Qual Prefer. 2013;28:356-60. doi: 10.1016/j.foodqual.2012.11.002.
14. Torrico DD, Nguyen P-T, Li T, Mena B, Viejo CG, Fuentes S, et al. Sensory acceptability, quality and purchase intent of potato chips with reduced salt (NaCl) concentrations. LWT-Food Sci Technol. 2019;102:347-55. doi: 10.1016/j.lwt.2018.12.050.

15. Reis F, Alcaire F, Deliza R, Ares G. The role of information on consumer sensory, hedonic and wellbeing perception of sugar-reduced products: case study with orange/pomegranate juice. Food Qual Prefer. 2017;62:227-36. doi: 10.1016/j.foodqual.2017.06.005.

16. Lima $M$, de Alcantara $M$, Ares $G$, Deliza R. It is not all about information! Sensory experience overrides the impact of nutrition information on consumers' choice of sugar-reduced drinks. Food Qual Prefer. 2019;74:1-9. doi: 10.1016/j.foodqual.2018.12.013.

17. Ebneter DS, Latner JD, Nigg CR. Is less always more? The effects of lowfat labeling and caloric information on food intake, calorie estimates, taste preference, and health attributions. Appetite. 2013;68:92-7. doi: 10.1016/j.appet.2013.04.023.

18. Carrillo E, Varela P, Fiszman S. Packaging information as a modulator of consumers' perception of enriched and reduced-calorie biscuits in tasting and non-tasting tests. Food Qual Prefer. 2012;25:105-15. doi: 10.1016/j.foodqual.2012.02.005.

19. Oliveira D, Ares G, Deliza R. The effect of health/hedonic claims on consumer hedonic and sensory perception of sugar reduction: case study with orange/passionfruit nectars. Food Res Int. 2018;108:111-8. doi: 10.1016/j.foodres.2018.03.003.

20. Schnettler B, Ares G, Sepulveda N, Bravo S, Villalobos B, Hueche C, et al. Are consumers willing to pay more for reformulated processed meat products in the context of the implementation of nutritional warnings? Case study with frankfurters in Chile. Meat Sci. 2019;152:104-8. doi: 10.1016/j.meatsci.2019.02.007.

21. de-Magistris T, Lopez-Galan B. Consumers' willingness to pay for nutritional claims fighting the obesity epidemic: the case of reducedfat and low salt cheese in Spain. Public Health. 2016;135:83-90. doi: 10.1016/j.puhe.2016.02.004.

22. Ares G, Aschemann-Witzel J, Curutchet MR, Antúnez L, Machín L, Vidal $L$, et al. Product reformulation in the context of nutritional warning labels: exploration of consumer preferences towards food concepts in three food categories. Food Res Int. 2018;107:669-74. doi: 10.1016/j. foodres.2018.03.021.

23. Nguyen $\mathrm{H}$, Wismer WV. A comparison of sensory attribute profiles and liking between regular and sodium-reduced food products. Food Res Int. 2019;123:631-41. doi: 10.1016/j.foodres.2019.05.037.

24. Ganesan B, Brown K, Irish DA, Brothersen C, MCMahon DJ. Manufacture and sensory analysis of reduced- and low-sodium cheddar and mozzarella cheeses. J Dairy Sci. 2014;97:1970-82. doi: 10.3168/ jds.2013-7443.

25. Chollet M, Gille D, Schmid A, Walther B, Piccinali P. Acceptance of sugar reduction in flavored yogurt. J Dairy Sci. 2013;96:5501-11. doi: $10.3168 /$ jds.2013-6610.

26. Vidal L, Ares G, Hedderley DI, Meyners M, Jaeger SR. Comparison of rate-all-that-apply (RATA) and check-all-that-apply (CATA) questions across seven consumer studies. Food Qual Prefer. 2018;67:49-58. doi: 10.1016/j.foodqual.2016.12.013.

27. Moher D., Liberati A., Tetzlaff J., Altman DG. The PRISMA group, 'Preferred reporting items for systematic reviews and meta-analyses: the PRISMA statement'. BMJ. 2009;339:b2535.

28. Roy Rosenzweig Center for History and New Media. Zotero, 2016.

29. Microsoft Corporation. Microsoft Excel, 2018.

30. Romagny S, Ginon E, Salles C. Impact of reducing fat, salt and sugar in commercial foods on consumer acceptability and willingness to pay in real tasting conditions: a home experiment. Food Qual Prefer. 2017;56:164-72. doi: 10.1016/j.foodqual.2016.10.009.

31. Kähkönen P, Tuorila H, Rita H. How information enhances acceptability of a low-fat spread. Food Qual Prefer. 1996;7:87-94. doi: 10.1016/09503293(95)00040-2. 
32. Stubenitsky K, Aaron JI, Catt SL, Mela DJ. Effect of information and extended use on the acceptance of reduced-fat products. Food Qual Prefer. 1999;10:367-76. doi: 10.1016/S0950-3293(98)00056-1.

33. Rodbotten M, Tomic O, Holtekjolen AK, Grini IS, Lea P, Granli BS, et al. Barley bread with normal and low content of salt; sensory profile and consumer preference in five European countries. J Cereal Sci. 2015;64:176-82. doi: 10.1016/j.jcs.2015.05.001.

34. Ritvanen T, Lilleberg L, Tupasela T, Suhonen U, Eerola S, Putkonen T, et al. The characterization of the most-liked reduced-fat havarti-type cheeses. J Dairy Sci. 2010;93:5039-47. doi: 10.3168/jds.2010-3304.

35. Bobowski N, Rendahl A, Vickers Z. A longitudinal comparison of two salt reduction strategies: acceptability of a low sodium food depends on the consumer. Food Qual Prefer. 2015;40:270-8. doi: 10.1016/j. foodqual.2014.07.019.

36. Schnettler B, Ares G, Sepúlveda N, Bravo S, Villalobos B, Hueche $C$, et al. How do consumers perceive reformulated foods after the implementation of nutritional warnings? Case study with frankfurters in Chile. Food Qual Pref. 2019;74:179-88. doi: 10.1016/j. foodqual.2019.01.021.

37. Shan LC, De Brun A, Henchion M, Li C, Murrin C, Wall PG, et al. Consumer evaluations of processed meat products reformulated to be healthier - a conjoint analysis study. Meat Sci. 2017;131:82-9. doi: 10.1016/j.meatsci.2017.04.239.

38. Tijssen I, Zandstra EH, de Graaf C, Jager G. Why a "light" product package should not be light blue: effects of package colour on perceived healthiness and attractiveness of sugar- and fat-reduced products. Food Qual Prefer. 2017;59:46-58. doi: 10.1016/j.foodqual.2017.01.019.

39. Pineli $L$ de $L$ de O, Aguiar LA de, Fiusa A, Botelho RB de A, Zandonadi RP, Melo L. Sensory impact of lowering sugar content in orange nectars to design healthier, low-sugar industrialized beverages. Appetite. 2016;96:239-44. doi: 10.1016/j.appet.2015.09.028.

40. Oliveira D, Galhardo J, Ares G, Cunha LM, Deliza R. Sugar reduction in fruit nectars: impact on consumers' sensory and hedonic perception. Food Res Int. 2018;107:371-7. doi: 10.1016/j.foodres.2018.02.025.

41. Oliveira D, Reis F, Deliza R, Rosenthal A, Gimenez A, Ares G. Difference thresholds for added sugar in chocolate-flavoured milk: recommendations for gradual sugar reduction. Food Res Int. 2016;89:448-53. doi: 10.1016/j.foodres.2016.08.019.

42. Oliveira D, Antunez L, Gimenez A, Castura JC, Deliza R, Ares G. Sugar reduction in probiotic chocolate-flavored milk: impact on dynamic sensory profile and liking. Food Res Int. 2015;75:148-56. doi: 10.1016/j. foodres.2015.05.050.

43. Johansen SB, Næs T, Øyaas J, Hersleth M. Acceptance of calorie-reduced yoghurt: effects of sensory characteristics and product information. Food Qual Pref. 2010;21:13-21. doi: 10.1016/j.foodqual.2009.07.003.

44. ISO. Sensory analysis-vocabulary. Standard 5492:2008. Brussels: Eur Comm Stand, 2008.

45. Franco-Arellano B, Vanderlee L, Ahmed M, Oh A, L’Abbé M. Influence of front-of-pack labelling and regulated nutrition claims on consumers' perceptions of product healthfulness and purchase intentions: a randomized controlled trial. Appetite. 2020;149:104629. doi: 10.1016/j. appet.2020.104629.

46. Spiteri M, Soler L-G. Food reformulation and nutritional quality of food consumption: an analysis based on households panel data in France. Eur J Clin Nutr. 2018;72:228-35. doi: 10.1038/s41430-017-0044-3.

47. WHO. Noncommunicable diseases: country profiles 2018. Geneva: World Health Organisation, 2018.

48. Czarnacka-Szymani J, Jezewska-Zychowicz M. Impact of nutritional information on consumers' acceptance of cheese with reduced sodium chloride content. Int Dairy J. 2015;40:47-53. doi: 10.1016/j. idairyj.2014.08.01.7.

49. Avery A, Bostock L, McCullough F. A systematic review investigating interventions that can help reduce consumption of sugar-sweetened beverages in children leading to changes in body fatness. J Hum Nutr Diet. 2015;28:52-64. doi: 10.1111/jhn.12267.
50. Webster J, Trieu K, Dunford E, Hawkes C. Target salt 2025: a global overview of national programs to encourage the food industry to reduce salt in foods. Nutrients. 2014;6:3274-87. doi: 10.3390/nu6083274.

51. Kovač B, Knific M. The perception of low-salt bread among preschool children and the role of educational personnel in creating a positive attitude towards reformulated food. Zdr Varst. 2017;56:39-46. doi: 10.1515/sjph-2017-0006. 